\title{
Academic staff challenges to effective utilization of information and communication technology (ICT) in teaching/learning of agricultural education
}

\author{
Azuh Oluchi Jannet*, Melody Ndidi Modebelu*,** \\ College of Agricultural \& Science Education, Michael Okpara University of Agric \\ Umudike, Abia State, Nigeria \\ *,**Tel. $+2348064710289,+2348035050452$ \\ ${ }^{*, \star * E-m a i l ~ a d d r e s s: ~ o l u c h i a z u h @ y a h o o . c o m ~, ~ m e l o o d y n e @ y a h ~}$
}

\section{ABSTRACT}

ICT has offered great potential, especially as an aid to aspect human endeavor. Inspire of the roles played by ICT especially in teaching/learning, th cre are still some pediments to its effective utilization by the academic staff. This work examin the academic staff challenges to effective utilization of ICT in teaching and learning of Agricultura zducation in Federal Universities in South East geopolitical zones of Nigeria. Forty respondents were $p$ sively sa npling from universities and used for the study. Three research questions guided the study. A i esearchers' developed questionnaire was used for data collection. Instrument valida ared face and content validity by two experts in

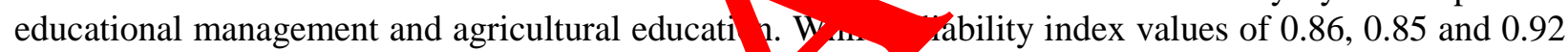
were obtained using Cronbach alpha. Means a grand means were used to analyze the research questions. The findings revealed a $\mathrm{com}$ tent uti ration and inadequate ICT tool literacy among the academic staff in the federal ur ersitic in south cast geo-political zone of Nigeria. It is therefore recommended that the acade ic of aselves the opportunity of various conferences and workshops to acquire the ne dedskilis effective utilization of ICT tools.

Keywords: ICT utiliza on; A vmic staf $y$, teaching, learning; Agricultural education

\section{INTRODU ON}

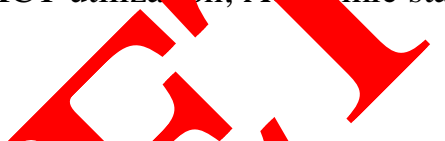

Agri dlture ha long been accepted as means of ensuring food security as well as emp as of a nation economically. Early 60s in Nigeria experienced economic boom th agricultural produce which had been the major sources of Nigerian economy until this int era of oil boom. The fact that Nigeria is presently monoeconomic nation has continued to be a source of worry, as it appears to be over-stretched for the maintenance of every sector of the nation. This gave rise to the need of repositioning agriculture for food security and national economic sustainable development, one of the strategies for the repositioning which led to the introduction of agricultural education as a programme of study in Nigerian tertiary institutions. Inability of teachers to utilize ICT to enhance effective teaching and learning has been the major problem of attaining the goals of agricultural education in Nigeria. It is in recognition of this that the urgent need to integrate ICT into 
university education arises. Inspite of the roles played by ICT in teaching/learning, there are still some impediments to its effective utilization by the academic staff.

\section{ACADEMIC STAFF AND ICT UTILIZATION}

Hornby (2000) defined utilization as the process of practical and effective usage of something. ICT learning and utilization is one of the concern of educational issues around the world and for a number of years, there has been evidence in the training and development area as noted by Edwards et al, (2006). This development can only be achieved the un computer (ICT) is effectively utilized. According to (Wikipedia, 2011) is $y$ to descr how resources are deployed and allocated which is comprised of a plapmed $\mathrm{rt}$ for $\mathrm{t}$ future and the actual effort in the past. ICT utilization therefore allows leaners to d ace ne teacher at the center of learning experience and take responsibility thei garnin $r o$ be learner-centered. This places a vital role on the teacher as the filis deper $s$ on the teachers. These teachers are referred to as academic staff at the rtiary le The academic staff therefore has been described by Modebelu and Onyali ( v) as gro of individuals that are employed in the universities and other tertiary in tion rain and groom students through higher level manpower training needs. They a guerally ca yized into male and female. They are professional whose duties are to te ch, instruct, train, educate and facilitate students' knowledge, learning and performance. A experts and professionals, these staff is expected to be versatile, creative, resourceful and in tive. Bu Inspite of the characteristics of these staff, it has been noted that the academic sta $\quad r$ been able to produce or turn out quality graduates as much as expecte nem due to their inability to utilize new technologies in teaching and up-dating of 1 sor to ces. Modebelu et al (2013) rightly pointed out therefore that the acadomic stat is expected to utilize their expertise online training to ensure the achieveme a or ality in heir products that will in turn help to achieve the set goals of Agricultura cati n as ens, irined in the national policy on education, (2004). No doubt, effecti ICT tools in the tertiary institutions by the academic staff especiay in teach, and learning of Agricultural education will help to produce efficient and fffe graduat, , to solve the problem of hunger.

\section{CHALL 'GES 9 EFFECTIVE UTILIZATION OF ICT TOOLS}

F rical s. es ave indicated that even teachers who have competence in the use of ICT do no integrat nem in their teaching. Problems of quality and lack of resources are com no new realities faced by higher education institutions battle to cope with every reasing student's numbers. Not only have higher education systems expanded worldwia $\%$ nature of the institution within these systems has also been shifting, through a process of differentiation (World Bank, 2000 as cited by Ololube, Ubogu \& Ossai, 2007). According to Pelgrum (2001), obstacles for ICT implementation include the following: Insufficient number of computers, teachers' lack of ICT knowledge/skills, difficult to integrate ICT to instruction, scheduling computer time, insufficient peripherals, not enough copies of software, insufficient teacher time, not enough simultaneous access, not enough supervision staff and lack of technical assistance. Similarly, Azuh (2013) noted the barriers also to include limited equipment, inadequate skills, minimal support, time constraints and the teacher's own lack of interest or knowledge about computer. Kwacha (2007) also noted that 
the most common problems associated with the effective implementation of ICT are lack of qualified ICT personnel, cost of equipment, management attitudes, inconsistent electric power supply, inadequate telephone lines, particularly in rural areas and non-inclusion of ICT programmes in teacher's training curricula and at the basic levels of education.

Also, these problems stated can affect or hinder the effective use of ICT by undergraduates if they are not properly implemented. For undergraduates in Nigerian universities to be abreast with the present information age, these facilities need to be put in place to enhance the teaching-learning process.

\section{PROSPECTS OF ICT USE IN UNIVERSITIES}

Despite the fact that Nigeria and in fact most African countries co ne late in the $\mathrm{V}_{\mathrm{L}} \mathrm{T}$ world, the adoption of the Nigerian policy for information technolog $/ 2001$ the $\mathrm{ri}_{c} /$ step in ICT application in every sector of the nation's life and in p tic a educ ion. The policy is designed to ensure that Nigeria as a nation recognize the stra im im ortance of ICT for national development. Successful application in ey ely ector can 1 y be assured through adequate coverage of needed areas. Identified aps be filled through the environment of important stakeholders/actors such as th ow her and of ers of education. Specifically, Kwacha (2007) indicated the following are some require, urgent steps towards the adoption and use of ICTs in education.

- The adoption of ICT international standards and inclus on in the Nigeria curriculum and in particular in the teacher's education riculum. cortinuous and provide training of teachers on computers and ICT skill acquisiti n.

- Development and training of ICT exp $\mathrm{r}^{\mathrm{r}} \sigma, \mathrm{sp}_{\mathrm{s}}$, ifically for instruction design and development, who will work in pa hip wit educators and teachers.

- Funding: Government at leve should ake ICT a matter of priority; improve the funds specifically needed fo tho ip chers/students in computer education who will be equipped with ICT kn wleuge à skills.

- There is need for a Vigerian g Ament to address seriously the issues of the erratic electricity power su $1 \mathrm{y}$ w on the other hand schools wishing to adopt the integration of ICT in their teag ang - learn, orocess should as a matter of urgency procure a generating set, that can sy oplem nt Power $y$ olding Company (PHCN) for supply of power.

\section{Research questions guided the study.}

1. To extent does the academic staff utilize the available ICT tools for effective teaching an $A$ learning of Agricultural Education?

2. What are the academic staff challenges to effective utilization of the ICT tools to enhance effective teaching and learning of Agricultural Education?

3. In what ways can the challenges to effective ICT tools utilization be redressed for effective teaching and learning of Agricultural Education? 


\section{METHODOLOGY}

The study adopted a descriptive survey design meant to assess opinion responses on the present situations. Two federal universities out of five federal universities in the south east geo-political zone were purposively sampled because they offer agricultural education. A total of 40 academic staff consisting of (17 male and 23 female), were selected from the two federal universities. Three research questions guided the study. Researchers' self designed questionnaire titled Academic Staff ICT Utilization for Effective Teaching and Learning Questionnaire (ASIUETLQ) was used for data collection. The 35- item-questionnoima was built on a 4-point scale. The instrument was validated by two experts in cducat 1 Administration and Agricultural Education on face and content validity. A lot test $\mathrm{h}$ conducted using 10 academic staff from 2 state universities in the same gopon zone Nigeria. A Cronbach alpha reliability values of $0.86,0.85$, and 0.92 wer obtain fo th ee clusters. All the 40 copies of the IUETLQ administered to 40 res ndent yere i arned through the assistance of a trained Research Assistants and it was y a a coly and grand means were used to answer the research questions. $\mathrm{ems}$ scon 2.50 and above were accepted as positive responses to the items while scoring o 2.50 were regarded as negative responses. ANOVA statistical tool $\mathrm{h} s$ uso test the hypothesis at 0.05 levels of significance

\section{RESULTS}

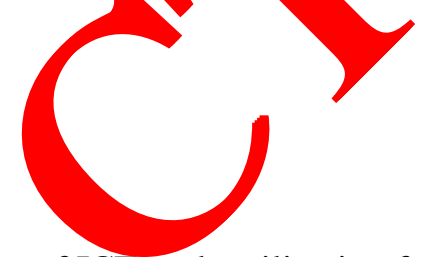

Table 1. Mean responses of academic staff on t of ICT tools utilization for effective teaching

\begin{tabular}{|c|c|c|c|c|}
\hline $\mathbf{S} / \mathbf{N}$ & Extent Of $y$ ilizat $n$ & $\begin{array}{l}\text { Male } \\
\text { esponse }\end{array}$ & $\begin{array}{c}\text { Female } \\
\text { Response }\end{array}$ & Remark \\
\hline 1 & & 3.35 & 3.13 & HEU \\
\hline 2 & & 1.41 & 1.61 & LEU \\
\hline 3 & & 1.71 & 1.87 & LEU \\
\hline & tation & 1.41 & 1.69 & LEU \\
\hline & & 3.00 & 3.22 & HEU \\
\hline & Video recorder & 1.76 & 1.69 & LEU \\
\hline & Interactive white board & 2.47 & 2.69 & LEU \\
\hline 8 & Television set & 1.94 & 2.00 & LEU \\
\hline 9 & Public address system & 2.65 & 2.52 & $\mathrm{HEU}$ \\
\hline 10 & Overhead projector & 2.59 & 2.65 & $\mathrm{HEU}$ \\
\hline & Grand Mean & 2.23 & 2.31 & \\
\hline
\end{tabular}


The result in Table 1 above revealed that items 2-8 have their mean responses below 2.50 indicating low extent utilization of the ICT tools enumerated. While on the other hand, only items 1, 5, 9 and 10 have their mean responses above 2.50 . The table also revealed grand means of 2.23 and 2.31 for male and female academic staff respectively. Both grand means score below the 2.50 indicating academic staff general agreement that the items enumerated are utilized in their institutions to a low extent.

Table 2. Mean responses of academic staff on challenges to effective utilization of ICT tools for effective teaching and learning of agricultural education.

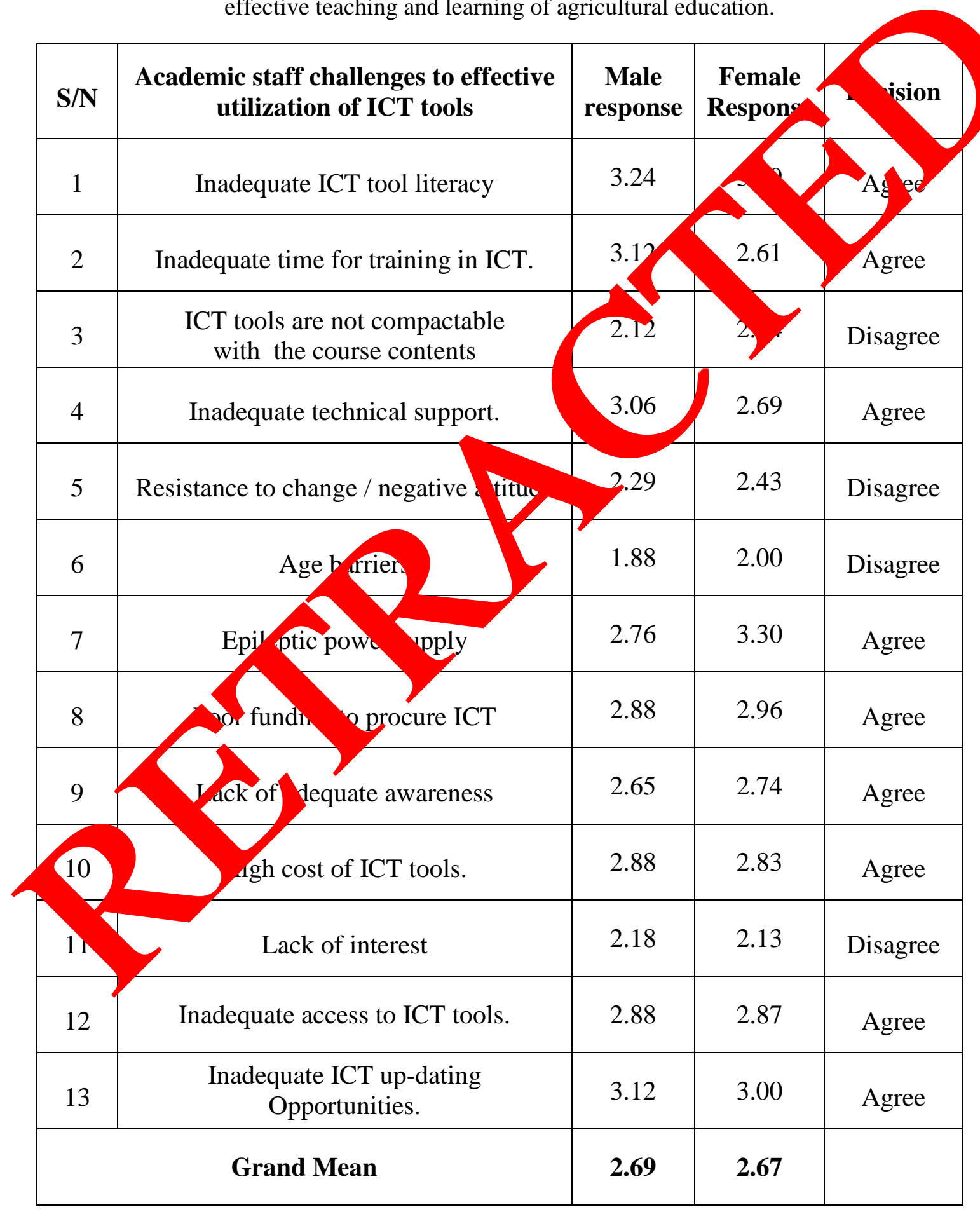


Result in Table 2 reveals grand means of 2.69 and 2.67 of male and female academic staff respectively. Both grand means scored above 2.50 (weighted mean) indicating academic staff general agreements that 9 out of the 13 enumerated items are the impeding factors to effective utilization of ICT tools. Four Items $(3,5,6$, and 11) does not serve as an impediment since they scored below 2.50, therefore the 9 items $(1,2,4,7-9,10,12$ and 13) are the academic staff challenges to ICT tools utilization of for effective teaching and learning of agricultural education. Item analysis revealed that academic staff inadequate ICT tool literacy is the most serious factor that challenged ICT utilization in the federal universities in south east geo political zone of Nigeria.

Table 3. Mean ratings of the Academic Staff on the ways of redressing the challengo ICT tools utilization for effective teaching and learning of Agricultural Educ on.

\begin{tabular}{|c|c|c|c|}
\hline $\mathbf{S} / \mathbf{N}$ & Ways of redressing the challenges include: & & Remark \\
\hline 1 & Allc & 3.45 & Agree \\
\hline 2 & Provision of adequate ha & 3.52 & Agree \\
\hline 3 & Adequate organization of ICT reso & 3.30 & Agree \\
\hline 4 & Government should pro & 3.37 & Agree \\
\hline 5 & Inclusion of ICT education into sc & 3.52 & Agree \\
\hline 6 & Establishment of effective ICT & 3.50 & Agree \\
\hline 7 & of ICT. & 3.55 & Agree \\
\hline 8 & ervice training. & 3.57 & Agree \\
\hline 9 & hools for free training. & 3.45 & Agree \\
\hline 10 & & 3.37 & Agree \\
\hline 11 & & 3.47 & Agree \\
\hline 12 & ng for the staff. & 3.67 & Agree \\
\hline & Grand Mean & \multicolumn{2}{|c|}{3.48} \\
\hline
\end{tabular}

Table 3 reveals grand mean of 3.48 on the ways of redressing the challenges of the Academic Staff on ICT tools utilization for effective teaching and learning. Since the grand means scored above 2.50 and item by item analysis scored also above 2.50 . This indicated that the academic staff generally agreed that all the 12 items serve as ways of redressing the challenges of the Academic Staff on ICT tools utilization for effective teaching and learning of Agricultural education in Nigeria federal Universities. 


\section{DISCUSSION}

The findings of this study were organized according to the research questions and they are presented below. Table 1 addresses the extent of utilization of the ICT tools for quality teaching and learning. The findings has shown that ICT tools that are expected to promote quality teaching and learning of agricultural education in Universities are utilized only to a low extent by the academic staff in south east geo political zone of Nigeria. This confirms the report of Effiong (2005) and Jegede and Owolabi (2008) that ICT materials such as computers, radio set, Skype, printers, scanners, video recorder, teleconferencing and bonks on ICT are not available and are not adequately being utilized in Nigerian secondar schoo, or computer education. Again, the findings agree with that of Seiden (2000) and $y$ egbu (20u for Nigeria which revealed a low level of usage of ICT equipment and facilities reconda schools. However, as a comparison, the findings are in contrast with th at of Bech $(20,0)$ that found US primary and secondary schools use computers in all sub cts, $p$ teaching of languages and mathematics.

The findings from research question two on the challen es to eft ve unization of ICT in teaching and learning revealed the major challe g to includu ne following: Inadequate ICT tool literacy, Inadequate time for train $\mathrm{g}$ in $\mathrm{TT}$, IC? tools are not compactable with the course contents, Inadequate tec now suppor, odstance to change / negative attitude, Age barriers, Epileptic power supp y, Poor funding to procure ICT, Lack of adequate awareness, High cost of ICT tools., Lack c interest, Ina lequate access to ICT tools, High cost of ICT tools, Lack of interest, Inadequate ess to IC tools. This is in accordance with the ideas of Pelgrum (2001), obstacle for ICT Insufficient number of computers, teache of ICT knowledge/skills, difficult to integrate ICT to instruction, scheduling com ter am Asufficient teacher time, not enough simultaneous access, not enough sumarvision s if and lack of technical assistance. Similarly, it agree with the findings of $\mathrm{Azy}_{1}(2 \mathrm{O})$ ) that $\mathrm{n}$ ted the barriers to include limited equipment, inadequate skills, minimal su tir e constro nts and the teacher's own lack of interest or knowledge about compute Ku also noted that the most common problems associated with the effe ve implen tation of ICT are lack of qualified ICT personnel; cost of equipment, manag me titudes, il onsistent electric power supply etc.

Result in $\mathrm{Ta}^{\mathrm{N}} \mathrm{e}$ india that the respondents generally agreed that Allocating enough time for traini g in ICT, Pro on of adequate hardware Adequate organization of ICT resources, G arnme shauld provide more funds for ICT, Inclusion of ICT education into school curricu. Estab hment of effective ICT system to carter for large audience, Creatin prope vare sess on the role of ICT, Training of staff on ICT utilization through in-s vice lining, $\mathrm{f}$ vision of adequate ICT Centre in schools for free training, Encouraging on tha tra gular training for the staff. The findings agree with Sundarajan (2005), Evoh 77), ana Nwana (2008a, 2008b, 2009a, 2009b) that teachers should have adequate training omputer education. Also, that necessary facilities and ICT tools should be provided forfective curriculum implementation in secondary school.

\section{CONCLUSION}

The study x-rayed that the Utilization of ICT in teaching and learning of Agricultural Education by the Academic Staff has not been fully effective in Federal Universities in South East geo-political zone of Nigeria due to Inadequate ICT tool literacy, inadequate ICT tools, 
Inadequate time for training in ICT, ICT tools are not compactable with the course contents, Inadequate technical support, Resistance to change / negative attitude among other challenges. The study also revealed twelve ways of redressing the challenges-Regular training for the staff, Allocating enough time for training in ICT, Provision of adequate hardware, Adequate organization of ICT resources, Government should provide more fund for ICT, Inclusion of ICT education into school curriculum, Establishment of effective ICT system to carter for large audience, Creating of proper awareness on the role of ICT, Training of staff on ICT utilization through in-service training, Provision of adequate ICT Centre in schools for free training, Encouraging online training, Administration ensuring that every staff owns laptop and the accessories. It is therefore recommended that the academic staff avail th inselvo opportunity of various conferences and workshops to acquire the needed ski for effect utilization of ICT tools.

\section{RECOMMENDATIONS}

Based on the findings, the following recommendations were $m$

Academic staff of universities should be encouraged t acc the need skills for the effective utilization of ICT facilities in our universities. as ameans of assuring effective teaching and learni g. Government ould encourage ICT tools utilization by ensuring adequate provision of tools and teclnologies necessary for promoting ICT tools effective utilization Academic ff of these higher insitutions should be assisted to have access to these technologies and of tunitie to acquire the needed skills through sponsorship of their attendance workshop and conferences. Government, university management and philanthropists hou ntribute towards adequate provision of ICT tools in universities.

\section{References}

[1] A. S. Hornby (2000, xford Adn Learners Dictionary, Special Price Edition. Oxford: Oxford nive Yress.

[2] Azuh O. J. 2013). Challer of Information and Communication Technology Impleme ation ong Federal Universities in Nigeria. An undergraduate research project, D Agric Education, MOUAU, Abia State.

[3] E S. P., ob A., Ellis R., The Assignment that triggered change: Assessment and elatid al learnt g model for generic capabilities. Assessment and Evaluation of Higher 29 2006) 141-157.

[4] Federa Republic of Nigeria, (2004). National Policy on Education. Lagos: Government press Ltd.

[5] FRN (2004). Nigerian National Policy on Education. Lagos: NERDC Press Institute of Education University of Ibadan (1985) Educational Technology. Ibadan Heinemann Educational Books (Nig) Ltd.

[6] Kwacha P. Z., The Imperative of Information and Communication Technologies for Teacher in Nigeria Higher Education. Merlot Journal of Online Learning and Teaching 3(4) (2007). 
[7] Modebelu M. N., Onyali L. C., Nigerian Journal of Educational Administration and Planning 11(3) (2011) 91-104.

[8] Ololube N. P., Ubogu A. E., Ossai A. G. (2007). ICT and Distance Education in Nigeria, A Review of Literature and Accounts. International Open and Distance Learning (IODL) Symposium.

[9] Onyali L. C., Modebelu M. N., Unizik Orient Journal of Education 6(1) (2011) 56- 69.

[10] Pelgrum W. J., Computer \& Education 37 (2001) 163-178.

[11] Wikipedia (2011). Free Encyclopedia. Retired on July 16, 2012 http://www.heros.inc.org/knowledgehtm

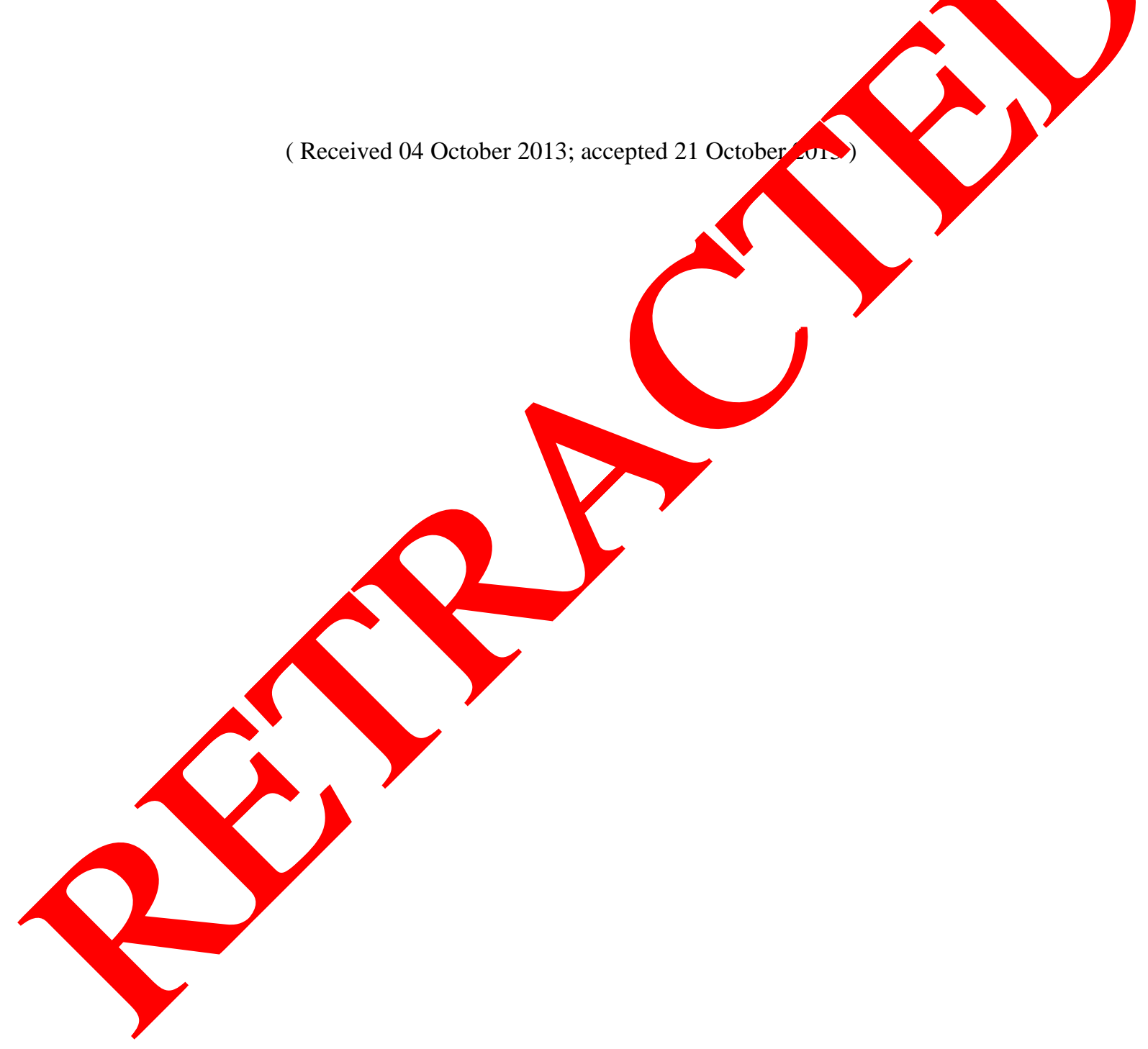

